\title{
ISSUES, CHALLENGES, AND POTENTIAL OF PALLIATIVE CARE IN PEDIATRIC NURSING: A SYSTEMATIC REVIEW
}

\author{
Aris Widiyanto, Rina Tri Handayani, Joko Tri Atmojo
}

School of Health Sciences Mamba'ul 'Ulum, Surakarta

\begin{abstract}
Background: Palliative care is an essential right for infants and children with a lifethreatening illness. However, palliative care is still unavailable in some developing countries. This study aimed to explore the issues, challenges, and potential of palliative care in pediatric nursing care.

Subjects and Method: A systematic review was conducted by searching published articles in PubMed, CINAHL, and EMBASE databases, from year 2000 to 2018. The keywords used for this study included "palliative" AND "children", "palliative" AND "nursing" AND "care", "palliative care" AND "pediatric care". The data were analyzed by PRISMA flow diagram.

Results: Palliative care is evolving continuously, meeting new challenges, and expanding beyond the care of terminally ill pediatric patients. A major challenge in palliative care is effective communication. However, only a few communication trainings exist for nurses. Obstacles of palliative care in pediatrics nursing included clinical, operational, and financial factors. However, palliative care has a substantial potential to reduce morbidity in infants and children. In addition, a cohort study conducted in 265 pediatric cancer patients reported that palliative care reduced pain and improved their life expectancy.

Conclusion: Palliative care is a comprehensive approach of care and its delivery to pediatric patients is challenging. It has a substantial potential in reducing infant and child morbidity.
\end{abstract}

Keywords: palliative care, pediatric nursing, palliative nursing

\section{Correspondence:}

Aris Widiyanto. School of Health Sciences Mamba'ul 'Ulum, Surakarta, Jl. Ring Road Utara, Tawangsari, Mojosongo, Jebres, Surakarta, Central Java. Email: widiyantoaris99@gmail.com. Mobile: 081329209095

The $6^{\text {th }}$ International Conference on Public Health Best Western Premier Hotel, Solo, Indonesia, October 23-24, 2019 | 143 